\title{
Diazotrophic bacteria in the growth of micropropagated ornamental pineapple
}

\section{Bacterias diazotróficas en el crecimiento de la piña ornamental micropropagada}
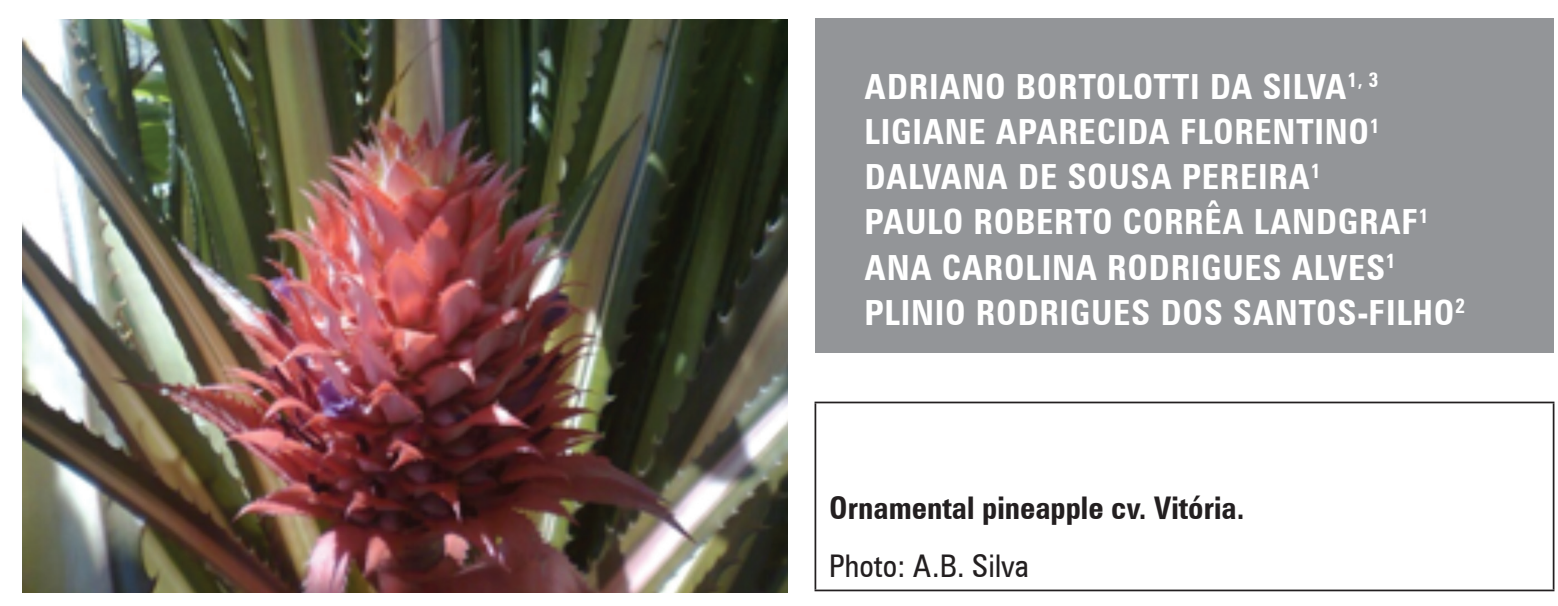

\section{ABSTRACT}

Ornamental pineapple is a hardy plant with significant landscaping value. Tissue culture of plants is viable for producing plants with a high phytosanitary quality. However, one of the difficulties with this cultivar is the acclimatization process, which is slow and can cause losses. The objective of the present study was to verify the potential of inoculation with diazotrophic bacteria for in vitro and ex vivo growth of ornamental pineapple. A group of diazotrophic bacterial strains selected at the Universidade José do Rosário Vellano (UNIFENAS) was prioritized in this study, and the treatments included bacterial strains UNIFENAS (10013, 100-60, 100-68, 100-153, 100-167 and 100-198). These strains were evaluated in terms of their capacity to produce indole 3-acetic acid. Subsequently, plants were cultivated in a medium composed of MS medium salts (1/4), adding $1 \mathrm{~mL}$ of the bacterial strain. In the control treatment, the plants were maintained in 2 $\mathrm{mL}$ of MS medium. 7 days after inoculation, the plants were transplanted into the MS, where they were maintained for 30 days. After in vitro cultivation, the plants were transferred to pots containing commercial Plantmax ${ }^{\circledR}$ substrate and maintained under these conditions for 60 days. The diazotrophic bacteria were able to synthesize auxins, and their inoculation promoted greater growth in vitro and ex vitro in the plants. In the acclimatization phase, the plants inoculated with UNIFENAS strains (100-60, 100-68 and 100-153) promoted a higher shoot growth, chlorophyll content and nitrate reductase enzyme activity.

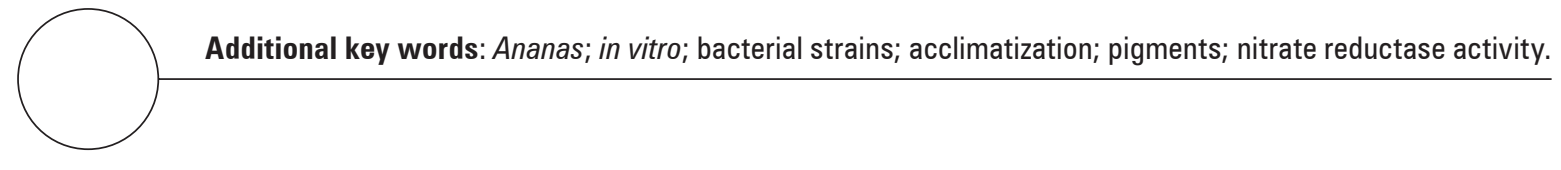

1 Universidade José do Rosário Vellano, Agronomy College, Alfenas (Brazil). ORCID Silva, A.B.: 0000-0003-1316-8243; ORCID Florentino, L.A.: 0000-0001-9092-3017; ORCID Pereira, D.S.: 0000-0002-7996-638X; ORCID Landgraf, P.R.C.: 0000-0002-2518-9159; ORCID Alves, A.C.R.: 0000-0002-0769-9219

2 Universidade Federal de Alfenas, Departament of Biochemistry, Alfenas (Brazil). ORCID Santos-Filho, P.R.: 0000-0001-8530-1977

3 Corresponding author. adriano.silva@unifenas.br 


\section{RESUMEN}

La piña ornamental es una planta rústica y de alto valor paisajístico. El cultivo de tejidos de la especie se muestra viable, produciendo plantas con alta calidad fitosanitaria. Una de las dificultades de ese cultivo es el proceso de aclimatación, que ocurre lentamente y puede causar pérdidas. El presente estudio tuvo como objetivo verificar el potencial de inoculación de las bacterias diazotróficas en el crecimiento in vitro y ex vitro de la planta de la piña ornamental. Un grupo de cepas de bacterias diazotróficas seleccionadas en la Universidade José do Rosário Vellano (UNIFENAS) fueron usadas en el estudio y las cepas bacterianas UNIFENAS 100-13, 100-60, 100-68, 100-153, 100167 y 100-198, constituyeron los tratamientos. Se evaluaron las cepas con relación a la capacidad de producir ácido indol-3-acético. Posteriormente, las plantas fueron cultivadas en medio MS (1/4) y $1 \mathrm{~mL}$ de la cepa bacteriana. En el tratamiento control se mantuvieron las plantas con $2 \mathrm{~mL}$ de medio MS. Después de 7 días de la inoculación, las plantas fueron trasplantadas a MS, donde permanecieron por un período de 30 días. Después del cultivo in vitro, las plantas fueron transferidas a materas con el substrato comercial Plantmax ${ }^{\circledR}$, donde se mantuvieron por 60 días en estas condiciones. Las bacterias son capaces de sintetizar auxinas y su inoculación promueve mayor crecimiento de las plantas in vitro y ex vitro. En la fase de aclimatación, las plantas inoculadas con cepas UNIFENAS 100-60, 10068 y 100-153, promovieron un mayor crecimiento de brotes, un mayor contenido de clorofila y una actividad de la enzima nitrato reductasa.

Palabras clave adicionales: Ananas; in vitro; cepas bacterianas; aclimatación; pigmentos; actividad nitrato reductasa.

Received for publication: 24-05-2018 Accepted for publication: 31-07-2019
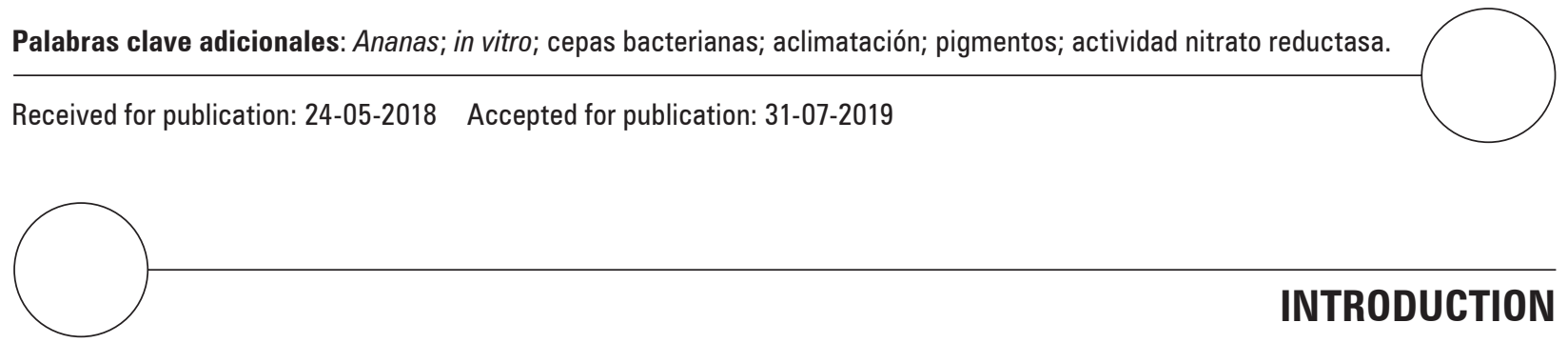

INTRODUCTION

Bromeliads are found in tropical regions, with around $70 \%$ of the genus having been identified and $40 \%$ of the species being native to Brazil. Ornamental pineapple belongs to the Bromeliacae family and is a species of great economic value, the third most sold bromeliad in the world. It is cultivated in Thailand, Costa Rica, Brazil, the Philippines, Indonesia and India (FAO, 2016).

Ananas comasus var. bracteatus is a native species widely used in landscaping to outline garden areas and flowerbeds (Oliveira et al., 2010), which is perennial and easily grown, and is appreciated for its beautiful leaves and flowers. One of the issues with its large-scale use, however, is the difficulty in finding seedlings with a high genetic and phytosanitary quality that meets the demands of the consumer market.

Conventional propagation methods for bromeliads generate a low number of shoots, as well as high indices of spreading disease (Matos et al., 2009). In this context, alternative methods such as stem sectioning (Freitas et al., 2012), propagation of the fruit crown (Santos et al., 2011) and micropropagation (Baldotto et al., 2010) are being investigated to try to minimize these problems.

Bromeliad micropropagation techniques produce healthy and standardized plants (Matos et al., 2009; Baldotto et al., 2010). However, plants obtained through in vitro cultivation have deficient anatomical and physiological characteristics, such as low quantities of cerinas, heterotrophic metabolism, thinner cuticles and external periclinal walls of the epidermal cells, low stomatic density (Barboza et al., 2006), poorly functioning roots and inactive photosynthetic structures (Souza et al., 2009). During acclimatization, they can present low survival rates (Hazarika, 2006), increasing the price of plants produced using this technology, which hampers their uptake by ornamental plant and floral producers.

A reduction of losses during the acclimatization phase can be achieved using better acclimatization periods (Berilli et al., 2011), leaf fertilization (Bregonci et al., 2008) and inoculation of micropropagated plants with diazotrophic bacteria, which have presented positive results in terms of adaptation to 
environmental changes by seedlings from in vitro pineapple cultivation (Baldotto et al., 2010).

Diazotrophic bacteria present beneficial effects on plant growth, such as biological fixation of nitrogen (Li et al., 2008) and solubilization of phosphate. They are also antagonistic to pathogenic species, produce plant hormones (indole-3-acetic acid - AIA) and promote plant growth (Moreira and Siqueira, 2002; Moreira et al., 2010). The AIA produced by these bacteria can increase the length and number of radicular hairs, increasing the exploration area of roots, thereby providing greater nutrient and water absorption and tolerance to low soil humidity conditions (Ryan et al., 2008; Moreira et al., 2010; Cassán et al., 2014).

Oliveira et al. (2006) related that results demonstrate the feasibility of the inoculation technology using diazotrophic bacteria in micropropagated sugarcane and plants grown in soils with low to medium levels of fertility. Dias et al. (2009), using diazotrophic bacteria strains, verified promoted root and plant shoot development. The plant growth promotion correlated with IAA production and phosphate solubilization. Bacterial effects could potentially be harnessed to promote plant growth during seedling acclimatization in strawberry.

Inoculation with diazotrophic bacteria can be a viable acclimatization strategy for pineapple plants propagated in vitro, producing hardier plants adapted to field conditions. Therefore, the present study aimed to determine the potential of diazotrophic bacteria for in vitro and ex vitro growth of ornamental Ananas comousus var. bracteus pineapple plants.

\section{MATERIAL AND METHODS}

\section{In vitro culture}

The present study was conducted in the Plant Biotechnology Laboratory of the Universida de José do Rosário Vellano (UNIFENAS), Alfenas-MG and established June, 2016. The plants were obtained with pineapple axillary buds culture (Ananas comosus var. bracteatus L.), which were inoculated in MS medium salts (Murashige and Skoog, 1962): $1.0 \mathrm{mg} \mathrm{L}^{-1}$ of BAP and $30 \mathrm{~g} \mathrm{~L}^{-1}$ of sucrose, solidified with $6 \mathrm{~g} \mathrm{~L}^{-1}$ of agar and $\mathrm{pH}$ adjusted to 5.8 before autoclaving at $121^{\circ} \mathrm{C}$ for $20 \mathrm{~min}$. Plants in the third subcultivation were stored in a growing room for $60 \mathrm{~d}$ with a temperature of $24 \pm 2^{\circ} \mathrm{C}, 16 \mathrm{~h}$ photoperiod and photosynthetic photon flux density of $36 \mu \mathrm{mol} \mathrm{m} \mathrm{m}^{-2} \mathrm{~s}^{-1}$.

Six diazotrophic bacterial strains belonging to the collection of the Agricultural Microbiology Laboratory of the UNIFENAS were isolated from soil samples and Brachiaria decumbens plant tissues, collected from soil located in southern Minas Gerais (Tab. 1). These strains have been tested for their potential to promote the growth of plants by Florentino et al. (2017) and Terra et al. (2019).

The bacterial strains were preserved in water according to the Romeiro (2001) methodology and reactivated and cultivated in a liquid FAM medium (Magalhães and Dobereiner, 1984) for $3 \mathrm{~d}$, enough time to reach the log growth phase, around $10^{9} \mathrm{UFC/}$ $\mathrm{mL}$. Prior to the inoculation with the bacteria together with the explant, the capacity of the strains (Tab. 1)

Table 1. Identification, medium used for bacteria isolation and morphological characteristics of strains cultured in FAM medium containing bromothymol blue as $\mathrm{pH}$ indicator.

\begin{tabular}{|c|c|c|c|c|}
\hline \multirow{2}{*}{ Strains } & \multirow{2}{*}{$\begin{array}{l}\text { Culture medium } \\
\text { of origin }\end{array}$} & \multicolumn{3}{|c|}{ Morphological characteristics in FAM medium } \\
\hline & & $\mathrm{pH}$ & Color & EPS \\
\hline UNIFENAS 100-13 & JNFb & Acid & Yellow & High \\
\hline UNIFENAS 100-60 & JNFb & Acid & Yellow & Medium \\
\hline UNIFENAS 100-68 & LGI & Acid & Yellow & Medium \\
\hline UNIFENAS 100-153 & FAM & Acid & Yellow & Medium \\
\hline UNIFENAS 100-167 & $\mathrm{NFb}$ & Acid & Yellow & Low \\
\hline UNIFENAS 100-198 & LGI & Acid & Yellowish & Medium \\
\hline
\end{tabular}

JNFb, Johanna nitrogen fixing bacteria medium; LGl, Lipman Glicose Ivo medium; FAM, initials used by the developer of medium (Magalhães and Döbereiner, 1984); $\mathrm{NFb}$, nitrogen fixing bacteria medium; EPS, production of exopolysaccharides. 
to produce 3-indoleacetic acid (AIA) in Dygs medium, both with and without $\left(100 \mu \mathrm{g} \mathrm{mL}{ }^{-1}\right)$ Tryptophan (Trp) was evaluated, according to the methodology described by Pedrinho et al. (2010). The experiment design was completely randomized, consisting of six bacterial strains in combination with tryptophan (presence/absence), totaling 12 treatments with four repetitions.

\section{Inoculation of diazotrophic bacteria}

The plants established in the previous phase were standardized with approximately $2 \mathrm{~cm}$ of length, with an aerial part and root system, inoculated in a solid medium containing $1 / 4$ of the concentration of the MS medium salts, with $5 \mathrm{~g} \mathrm{~L}^{-1}$ sucrose and $7 \mathrm{~g} \mathrm{~L}^{-1}$ agar, and maintained under these conditions for $30 \mathrm{~d}$.

The treatments were composed of different diazotrophic bacterial strains: UNIFENAS 100 (13, 60, 68, 153, 167 and 198) and a control treatment. The experimental design was completely randomized, containing seven treatments with three repetitions and three plants per parcel.

Diazotrophic bacteria were inoculated together with the plants in vitro for a period of $7 \mathrm{~d}$, with the application of $1 \mathrm{~mL}$ of cultivation medium with the bacteria added to $1 \mathrm{~mL}$ of the previously described MS culture medium ( $1 / 4)$, totaling $2 \mathrm{~mL}$ of solution per container for the different treatments. In the control treatment, only $2 \mathrm{~mL}$ of MS medium (1/4) were added. The cultivation was conducted in a growing room at a temperature of $25^{\circ} \mathrm{C}$, with a 12 -h photoperiod and light intensity of $36 \mu \mathrm{mol}$ photons $\mathrm{m}^{-2} \mathrm{~s}^{-1}$.

\section{Acclimatization}

After the in vitro culture, the plants were transferred to containers $\left(100 \mathrm{~cm}^{3}\right)$ with the commercial Plantmax ${ }^{\circledR}$ substrate and maintained in an arco model greenhouse with plastic covering and shade cloth siding (50\% shading), with a temperature between 16 and $29^{\circ} \mathrm{C} \pm 1{ }^{\circ} \mathrm{C}$ and $70 \%$ UR. The plants were maintained under these conditions for a period of $60 \mathrm{~d}$.

\section{Evaluations}

IAA Quantification. The indole acetic acid (IAA) concentration was evaluated using the colorimetric quantitative method (Gordon and Weber, 1951) during the log phase for bacterial growth, presenting approximately $10^{9} \mathrm{UFC} / \mathrm{mL}$. The estimation of the IAA quantification during the in vitro cultivation of diazotrophic bacteria was realized with the help of the standard-curve previously obtained with the sterilized Dygs medium and with the known IAA concentrations $\left(0,25,50,75\right.$ and $\left.100 \mu \mathrm{g} \mathrm{mL}^{-1}\right)$. The absorbance reading was realized using a spectrophotometer with a $5353 \mathrm{~nm}$.

Phytotechnics. The height of the aerial part, number of leaves, root system length and plant dry mass were evaluated.

Chlorophyll content and nitrate reductase enzyme activity. For the chlorophyll content analysis, two fully expanded leaves were collected by repetition. $0.1 \mathrm{~g}$ of leaf was macerated in $5 \mathrm{~mL}$ of $80 \%$ acetone. The extract was filtered through fiberglass, and the volume was completed with $10 \mathrm{~mL}$ of $80 \%$ acetone. The readings were realized at 663 and $647 \mathrm{~nm}$ with a light absorption spectrophotometer (A) (Arnon, 1949). For the calculation of chlorophyll ( $\mu \mathrm{g}$ chlorophyll/ $\mathrm{mL}$ ), the following equations were used: chlorophyll $a=(12.25 \times A 663)-(2.79 \times A 647)$; chlorophyll $b=$ $(21.50 \times A 647)-(5.10 \times A 663) ;$ total chlorophyll $=$ chlorophyll a + chlorophyll $b$.

The Nitrate reductase enzyme activity (ANR) was determined using the methodology proposed by Cataldo (1975). Leaves were cut into small pieces, and $200 \mathrm{mg}$ were placed in a $15 \mathrm{~mL}$ test tube with a stopper that contained $4 \mathrm{~mL}$ of $\mathrm{KNO}_{3} 0.25 \mathrm{M}$ in phosphate buffer. Subsequently, $1 \mathrm{~mL}$ of alpha-napthylamine and $1 \mathrm{~mL}$ of sodium acetate buffer were added, completing the volume with $50 \mathrm{~mL}$ of distilled water. The reading was realized with a Spectrophotometer adjusted to $540 \mathrm{~nm}$. Both evaluations were realized at the end of plant acclimatization.

The data were submitted to analysis of variance (ANOVA) using the statistical program Sisvar 5.3 (Ferreira, 2011), with the values compared using the Scott-Knott test at $5 \%$ probability.

\section{RESULTS AND DISCUSSION}

The IAA production was directly affected by the interaction $(P \leq 0.05)$ of the factors (bacterial strains and tryptophan). The use of tryptophan (TRP) in the culture medium promoted greater indole acetic acid (IAA) production, mainly with the UNIFENAS 
Table 2. Indol acetic acid (IAA, $\mu \mathrm{g} \mathrm{mL}^{-1}$ ) production by bacterial strains in Dygs medium, with and withou tryptophan.

\begin{tabular}{|c|c|c|c|c|c|c|}
\hline \multirow{2}{*}{ Medium } & \multicolumn{5}{|c|}{ Bacterial strains } \\
\cline { 2 - 7 } & $100-13$ & $100-60$ & $100-68$ & $100-153$ & $100-167$ & $100-198$ \\
\hline A TRP* & $0.91 \pm 0.03 \mathrm{Aa}$ & $0.33 \pm 0.01 \mathrm{Bb}$ & $0.47 \pm 0.1 \mathrm{Bb}$ & $0.42 \pm 0.1 \mathrm{Bb}$ & $1.51 \pm 0.1 \mathrm{Aa}$ & $0.50 \pm 0.1 \mathrm{Bb}$ \\
\hline P TRP & $1.26 \pm 0.40 \mathrm{Aa}$ & $1.28 \pm 0.22 \mathrm{Aa}$ & $0.94 \pm 0.1 \mathrm{Ab}$ & $1.33 \pm 0.4 \mathrm{Aa}$ & $1.42 \pm 0.2 \mathrm{Aa}$ & $1.46 \pm 0.1 \mathrm{Aa}$ \\
\hline
\end{tabular}

Means with different capital letters in a column and lower case in a row indicate a significant statistical difference according to the Scott-Knott test $(P \leq 0.05)$ $(n=4) \pm$ standard error. *A TRP, absence of tryptophan; P TRP, presence of tryptophan.

100-60, 100-68, 100-153 and 100-198 strains, as compared with the strains cultivated in the culture medium without TRP (Tab. 2).

Biosynthesis of auxins by bacteria occurs via different metabolic pathways (Spaepen et al., 2007), with TRP being the main precursor for IAA synthesis - a fact that explains the high indole values detected in the culture mediums that had TRP in comparison with those that did not, except for the 100-167 UNIFENAS and 100-13 UNIFENAS strains, which produced high IAA concentrations both with and without TRP
(Tab. 1). Similar results were observed by Baldotto et al. (2010), who found higher IAA synthesis values in bromeliad seedlings cv. Vitória when adding TRP to the culture mediums. Studies developed by Pedrinho et al. (2010) and Florentino et al. (2017) showed that the Ab-V5 strain produced a greater quantity of IAA when cultivated in medium containing TRP (Tab. 2).

The results for the bromeliads cultivated in vitro and inoculated with different bacterial strains showed greater growth in the aerial part (LPA) of the plants cultivated in vitro with the UNIFENAS 100-13 and
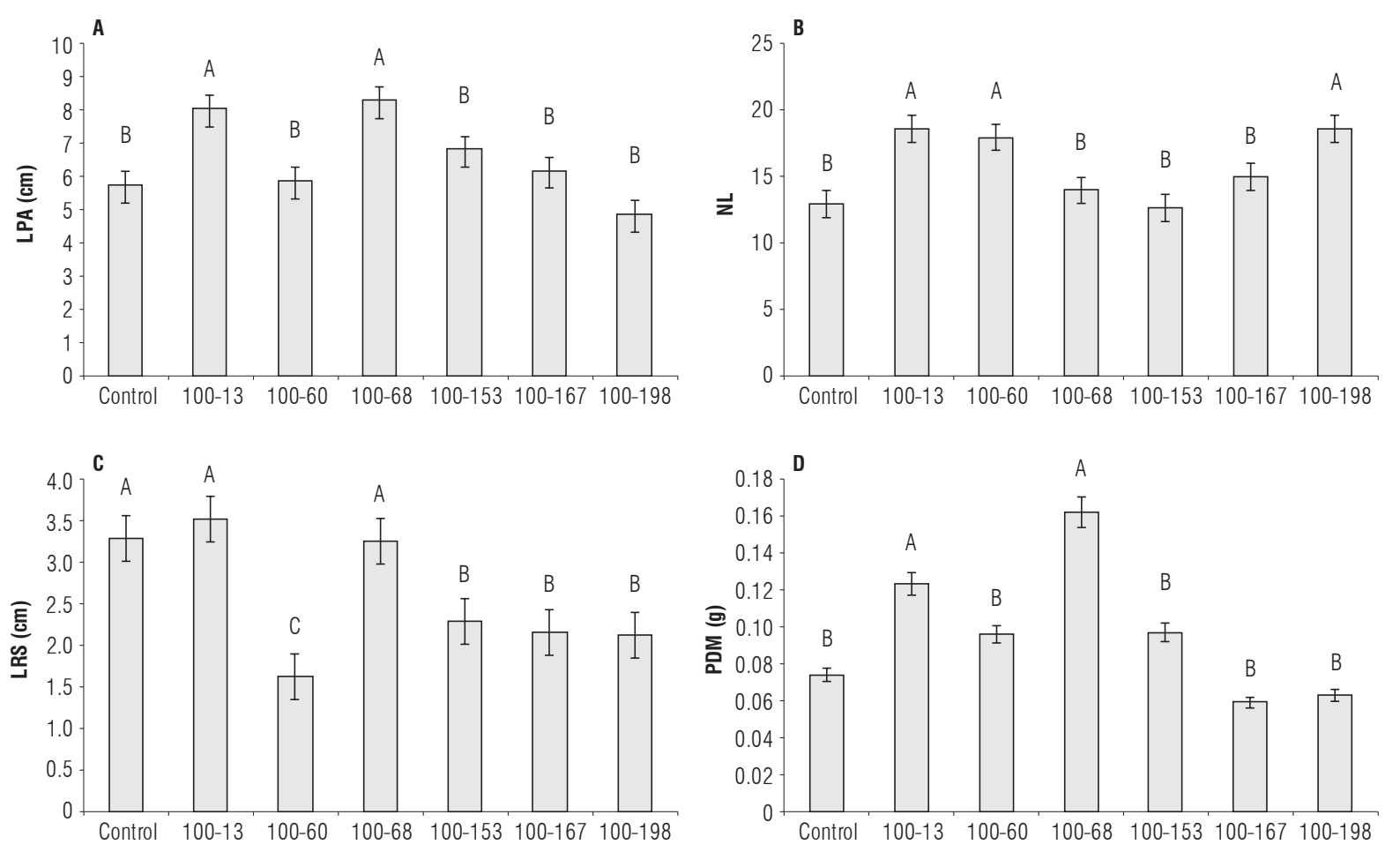

Figure 1. A) length of aerial part (LAP); B) length of root system (LRS); C) number of leaves (NL); D) plant dry mass (PDM) of ornamental pineapple plants cultivated in vitro $30 \mathrm{~d}$ with diazotrophic bacteria. Means with different letters indicate significant statistical difference according to the Scott-Knott test $(P \leq 0.05)(n=4) \pm$ standard error. 
UNIFENAS 100-68 strains, $2.5 \mathrm{~cm}$ larger than plants cultivated in the control treatment (Fig. 1A). This greater growth of the aerial part led to greater accumulation of dry mass in plants cultivated in vitro and inoculated with the UNIFENAS 100-13 and 100-68 strains (Fig. 1D).

The plants inoculated with the UNIFENAS 100-13, UNIFENAS 100-60 and UNIFENAS 100-198 strains presented a larger number of leaves (NL) (Fig. 1B). The size of the root system (LRS) of the in vitro bromeliad plants was directly affected by the bacterial strains, with UNIFENAS 100-13 and UNIFENAS 100-68 strains providing greater growth. However, they did not differ from the control treatment, which was greater than the other treatments (Fig. 1C).

Of the strains tested, it was found that inoculation with UNIFENAS 100-13 led to a significant effect on all the evaluated parameters, LPA, NL, LRS and PDM, which could be related to IAA production by this strain, both with and without TRP (Tab. 1). However, it was observed that the other strains, such as UNIFENAS 100-68, UNIFENAS 100-60 and UNIFENAS 100-198 also contributed significantly to in vitro cultivation of ornamental pineapple, suggesting a need for further research taking into consideration the possibility of co-inoculation.

During the acclimatization process in the ex vitro cultivation, the strains directly affected plant growth (Fig. 2). The UNIFENAS 100-167 strain provided greater growth for the aerial part (LPA) (Fig. 2A). The UNIFENAS 100-60, UNIFENAS 100-68, UNIFENAS 100-153 strains promoted dry mass accumulation (PDM) (Fig. 2AD), which was greater than in the other treatments (Fig. 2D). The inoculation of the plants with better strains resulted in an increase of 1.5 and $5.0 \mathrm{~cm}$ for LPA, accumulating 30 to $60 \%$ more PDM than in the plants submitted to the control treatment (Fig. 2AD).

The NL and LRS were also affected by inoculation in plants with different strains (Fig. 2, B and C). A greater LRS was observed in the plants inoculated with the UNIFENAS 100-167 strain. For NL, inoculation of
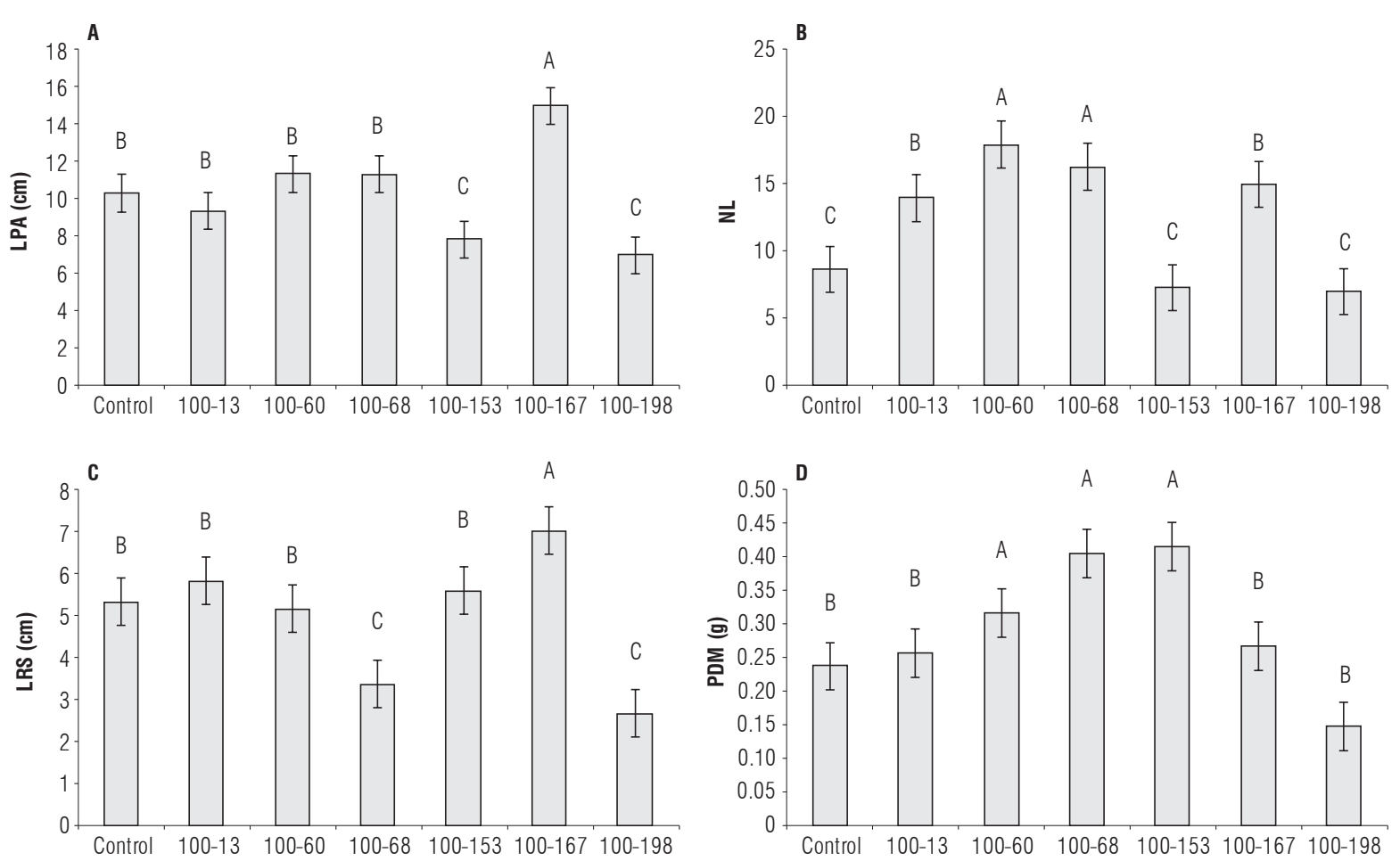

Figure 2. A) length of aerial part (LAP); B) length of root system (LRS); C) number of leaves (NL); D) plant dry mass (PDM) of ornamental pineapple plants cultivated ex vitro (acclimatization) $60 \mathrm{~d}$ with diazotrophic bacteria. Means with different letters indicate a significant statistical difference according to the Scott-Knott test $(P \leq 0.05)(n=4) \pm$ standard error. 


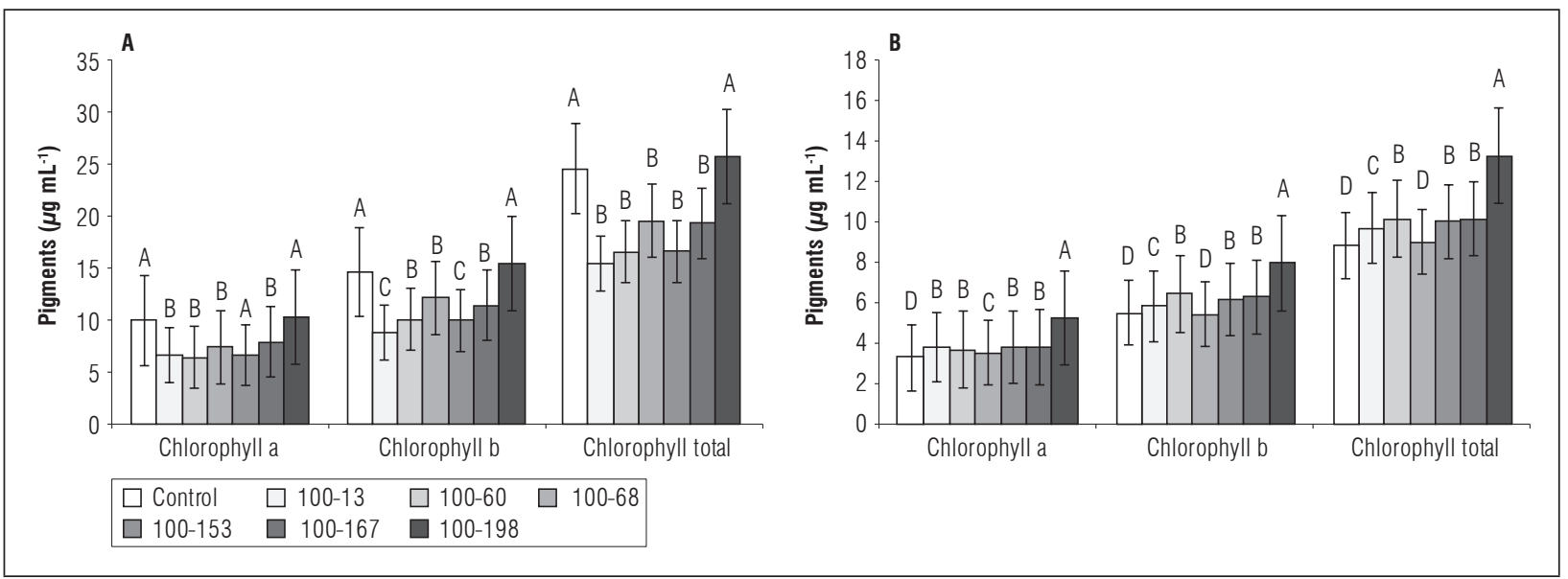

Figure 3. Content of pigments in ornamental pineapple plant inoculated with diazotrophic bacteria in vitro $(A)$ and ex vitro $(B)$ conditions. Means with different letters indicate a significant statistical difference according to the Scott-Knott test $(P \leq 0.05)(n=4) \pm$ standard error.

plants with the UNIFENAS 100-60 and UNIFENAS 100-68 strains presented a greater number of leaves (Fig. 2B). Inoculation with bacteria led to greater dry mass and root numbers in acclimatized bromeliad cv. Vitória plants (Silva et al., 2016), which was observed for some strains in the present study (Fig. 2).

The promotion of plant growth through inoculation with diazotrophic bacterial strains has already been observed in some agricultural species, such as tomato (Szilagyi-Zecchin et al., 2015), rice (Sabino et al., 2012), and lettuce (Schlindwein et al., 2008; Florentino et al., 2017). The beneficial effects of inoculation with these bacteria are related to the fixation of nitrogen, solubilization of phosphate, their antagonistic action against pathogenic species and production of plant hormones such as auxins, all of which promote plant growth (Moreira et al., 2010).

Generally, the pigment levels were greater in the in vitro culture than in the ex vitro cultivation (Fig. 3). This may be related to the lower light intensity during cultivation in the growing room (in vitro), making the plants invest more in biosynthesis of pigments, seeking to compensate for the reduction in photosynthesis as a result of the low light intensity. Amâncio et al. (1999) and Carvalho et al. (2001) reported that an increase in light intensity during acclimatization diminished the pigment levels in grape vines in an in vitro culture.

The UNIFENAS 100-198 strain and control treatment presented higher $\mathrm{a}, \mathrm{b}$ and total chlorophyll levels in the in vitro culture than in the other treatments (Fig. 3A). During the acclimatization process of the ex vitro plants, similar to what was observed with plants cultivated in vitro, the UNIFENAS 100198 strain presented higher $\mathrm{a}, \mathrm{b}$ and total chlorophyll levels. However, the control treatment of ex vitro plants presented lower $\mathrm{a}, \mathrm{b}$ and total chlorophyll levels (Fig. 3B). Inoculation with bacterial strains promoted higher a, b, and total chlorophyll levels than in the non-inoculated plants (Fig. 3B).

The higher photosynthetic pigment levels in the plants inoculated with different bacterial strains when compared with the control plants (Fig. 3) could be related to nitrogen, probably as a result of the biological fixation of nitrogen (Li et al., 2008). Nitrogen is a nutrient positively correlated with an increase in pigment levels in the leaves (Argenta et al., 2001; Lima et al., 2009). In this research, it was observed that the contribution of bacteria promoted plant growth by providing IAA and nitrogen to plant metabolism, resulting in the biomass accumulation observed in the plants during acclimatization (Fig. 2).

The UNIFENAS 100-60, 100-68 and 100-153 bacterial strains promoted nitrate reductase enzyme activity (ANR) (Fig. 4). Nitrate reductase is linked to a reduction of nitrate to nitrite that is subsequently transformed into ammonia and finally assimilated in glutamine by glutamine synthetase (Taiz et al., 2017).

Donato et al. (2004) and Marcos et al. (2016) indicated that the influence of bacteria on nitrogen metabolism 
is via an increase in ANR, which increases the entry of nitrate and, consequently, promotes an increase in the nitrogen levels in the plant with a greater resulting growth. This may have positively influenced the growth of the plants inoculated with the UNIFENAS 100-60, 100-68 and 100-153 strains (Fig. 4), which presented a greater ANR, as well as a greater dry mass accumulation (PDM) (Fig. 2D). The greater ANR activity could be considered for both the biological fixation of nitrogen and the promotion of greater nitrate absorption by the bacteria (Bashan and Levanony, 1990).

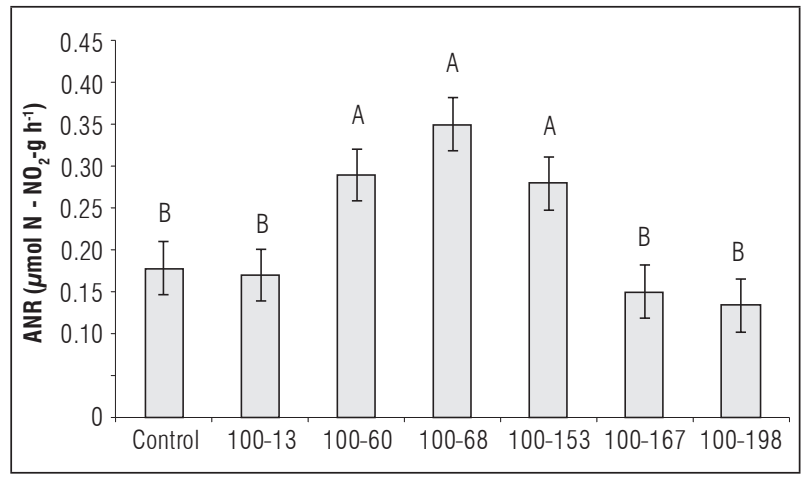

Figure 4. Nitrate reductase enzyme activity (ANR) in ex vitro ornamental pineapple plants with diazotrophic bacteria. Means with different letters indicate a significant statistical difference according to the Scott-Knott test $(P \leq 0.05)(n=4) \pm$ standard error.

\section{CONCLUSION}

Diazotrophic bacteria are capable of synthesizing auxins (IAA), and their inoculation in plants promotes greater growth during in vitro cultivation and acclimatization phases.

Conflict of interests: the manuscript was prepared and reviewed with the participation of all the authors, who declare that there exists no conflict of interest that puts at risk the validity of the presented results.

\section{BIBLIOGRAPHIC REFERENCES}

Amâncio, S., J.P. Rebordão, and M.M. Chaves. 1999. Improvement of acclimatization of micropropagated grapevine: photosynthetic competence and carbono allocation. Plant Cell Tiss. Org. Cult. 58(1), 31-37. Doi: 10.1023/A:1006323129593
Argenta, G., P.R.F. Silva, and C.G. Bortoloni. 2001. Clorofila na folha como indicador do nível de nitrogênio em cereais. Ciênc. Rural 31(4), 715-722. Doi: 10.1590/ S0103-84782001000400027

Arnon, D.I. 1949. Copper enzymes in isolated chloroplasts. Polyphenoloxidase in Beta vugaris. Plant Physiol. 24(1), 1-15. Doi: $10.1104 /$ pp.24.1.1

Baldotto, L.E.B., M.A. Baldotto, F.L. Olivares, A.P. Viana, and R. Bressan-Smith. 2010. Seleção de bactérias promotoras de crescimento no abacaxizeiro cultivar Vitória durante a aclimatização. Rev. Bras. Ciênc. Solo 34(2), 349-360. Doi: 10.1590/S0100-06832010000200008

Barboza, S.B.S.C., D. Graciano-Ribeiro, J.B. Teixeira, T.A. Portes, and L.A.C. Souza. 2006. Anatomia foliar de plantas micropropagadas de abacaxi. Pesq. Agropec. Bras. 41(2), 185-194. Doi: 10.1590/S0100204X2006000200002

Bashan, Y. and H. Levanony. 1990. Current status of Azospirillum inoculation technology: Azospirillum as a challange for agriculture. Can. J. Microbiol. 36(9), 591608. Doi: $10.1139 / \mathrm{m} 90-105$

Berilli, S.S., A.J.C. Carvalho, S.J. Freitas, D.C. Farias, and C.S. Marinho. 2011. Avaliação do desenvolvimento de diferentes tamanhos de mudas micropropagadas de abacaxizeiro, após aclimatação. Rev. Bras. Frutic. 33(1) 208-214. Doi: 10.1590/S0100-29452011005000018

Bregonci, S.I., E.F. Reis, G.D. Almeida, V.J. Brum, and M. Zucoloto. 2008. Avaliação do crescimento foliar e radicular de mudas micropropagadas do abacaxizeiro cv. gold em aclimatação. Idesia 26(3), 87-96. Doi: 10.4067/S0718-34292008000300010

Carvalho, L.C., M.L. Osório, M.M. Chaves, and S. Amâncio. 2001. Chlorophyll fluorescence as an indicator of photosynthetic functioning of in vitro grapevine and chestnut plantlets under ex vitro acclimatization. Plant Cell Tiss. Org. Cult. 67(3), 271-280. Doi: 10.1023/A:1012722112406

Cassán, F., J. Vanderleyden, and S. Spaepen. 2014. Physiological and agronomical aspects of phytohormone production by model Plant-Growth-Promoting Rhizobacteria (PGPR) belonging to the Genus Azospirillum. J. Plant Growth Regul. 33(2), 440-459. Doi: 10.1007/ s00344-013-9362-4

Cataldo, D.A., M. Haaroon, L.E. Schrader, and V.L. Young. 1975. Rapid colorimetric determination of nitrate in plant tissue by nitration of salicylic acid. Comm. Soil Sci. Plant Anal. 6(1), 71-80. Doi: 10.1080/00103627509366547

Dias, A.C.F., F.E.C. Costa, F.D. Andreote, P.T. Lacava, M.A. Teixeira, L.C. Assumpção, W.L. Araújo, J.L. Azevedo, and I.S. Melo. 2009. Isolation of micropropagated strawberry endophytic bacteria and assessment of their potential for plant growth promotion. World J. 
Microbiol. Biotechnol. 25(2), 189-195. Doi: 10.1007/ s11274-008-9878-0

Donato, V.M.T.S., A.G. Andrade, E.S. Souza, J.G. França, and G.A. Maciel. 2004. Atividade enzimática em variedades de cana-de-açúcar cultivadas in vitro sob diferentes níveis de nitrogênio. Pesq. Agropec. Bras. 39(11), 1087-1093. Doi: 10.1590/S0100-204X2004001100006

FAO. 2016. FAOSTAT. In: http://faostat.fao.org/; consulted: September, 2016.

Ferreira, D.F. 2011. Sisvar: a computer statistical analysis system. Ciênc. Agrotec. 35(6), 1039-1042. Doi: 10.1590/S1413-70542011000600001

Florentino, L.A., A.B. Silva, P.R.C. Landgraf, and F.R.C. Souza. 2017. Inoculação de bactérias produtoras de ácido 3-indol acético em plantas de alface (Lactuca sativa L.). Rev. Colomb. Cienc. Hortic. 11(1), 89-96. Doi: 10.17584/rcch.2017v11i1.5780

Freitas, S.J., P.C. Santos, A.J.C. Carvalho, S.S. Berilli, and M.M.A. Gomes. 2012. Brassinosteroide e adubação nitrogenada no crescimento e estado nutricional de mudas de abacaxizeiro provenientes do seccionamento de caule. Rev. Bras. Frutic. 34(2), 612-618. Doi: 10.1590/ S0100-29452012000200037

Gordon, S.A. and R.P. Weber. 1951. Colorimetric estimation of indoleacetic acid. Plant Physiol. 26(1), 192-195. Doi: 10.1104/pp.26.1.192

Hazarika, B.N. 2006. Morpho-physiological disorders in in vitro culture of plants. Sci. Hortic. 108(2), 105-120. Doi: 10.1016/j.scienta.2006.01.038

Li, J.H., E.T. Wang, W.F. Chen, and W.X. Chen. 2008. Genetic diversity and potencial for promotion of plant growth detected in nodule endophtic bacteria of soybean grown in Heilongiiang province of China. Soil Biol. Biochem. 40(1), 238-246. Doi: 10.1016/j. soilbio.2007.08.014

Lima, M.G.S., C.R. Mendes, R. Nascimento, N.F. Lopes, and M.A.P. Carvalho. 2009. Avaliações bioquímicas das plantas de milho pulverizadas com ureia isolada e em associação com aminoácidos. Ceres 53(3), 358-363.

Magalhães, F.M.M. and J. Döbereiner. 1984. Ocorrência de Azospirillum amazonense em alguns ecossistemas da Amazônia. R. Microbiol. 15(4), 246-252.

Marcos, F.C.C., R.P.F. Iório, A.P.D. Silveira, R.V. Ribeiro, E.C. Machado, and A.M.M.A. Lagoa. 2016. Endophytic bacteria affect sugarcane physiology without changing plant growth. Bragantia 75(1), 1-9. Doi: 10.1590/1678-4499.256

Matos, A.P., N.F. Sanches, F.A. Teixeira, A.H. Simão, D.C. Gomes, and J.E. Júnior. 2009. Monitoramento da fusariose em plantios de abacaxi 'Pérola' conduzidos em sistema de produção integrada no Estado do Tocantins. Documentos 184. Embrapa Mandioca e Fruticultura Tropical, Cruz das Almas, Brazil.
Moreira, F., K. Silva, R.S.A. Nobrega, and F. Carvalho. 2010. Bactérias diazotróficas associativas: diversidade, ecologia e potencial de aplicações. Com. Sci. 1(2), 74-99.

Moreira, F.M.S. and J.O. Siqueira. 2002. Microbiologia e bioquímica do solo. 2nd ed. Editora UFLA, Lavras, Brazil.

Murashige, T. and F. Skoog. 1962. A revised medium for rapid growth and bio assays with tabacco tissue cultures. Physiol. Plant. 15(3), 473-497. Doi: 10.1111/ j.1399-3054.1962.tb08052.x

Oliveira, Y., J.I. Anselmini, F.L. Cuquel, F. Pinto, and M. Quoirin. 2010. Pré-aclimatização in vitro de abacaxi-ornamental. Ciênc. Agrotec. 34 (Num. Spe.), 1647-1653. Doi: 10.1590/S1413-70542010000700010

Oliveira, A.L.M., E.L. Canuto, S. Urquiaga, V.M. Reis, and J.I. Baldani. 2006. Yield of micropropagated sugarcane varieties in different soil types following inoculation with diazotrophic bacteria. Plant Soil 284(1-2), 23-32. Doi: 10.1007/s11104-006-0025-0

Pedrinho, E.A.N., R.R. Galdiano Júnior, J.C. Campanharo, L.M.C. Alves, and E.G.M. Lemos. 2010. Identificação e avaliação de rizobactérias isoladas de raízes de milho. Bragantia 69(4), 905-911. Doi: 10.1590/ S0006-87052010000400017

Romeiro, R.S. 2001. Métodos em bacteriologia de plantas. Editora UFV, Viçosa, Brazil.

Ryan, R.P., K. Germaine, A. Franks, D.J. Ryan, and D.N. Dowling. 2008. Bacterial endophytes: recent developments and applications. FEMS Microbiol Lett. 278(1), 1-9. Doi: 10.1111/j.1574-6968.2007.00918.x

Sabino, D.C.C., J.S. Ferreira, S.L. Guimarães, and V.L.D. Baldani. 2012. Bactérias diazotróficas como promotoras do desenvolvimento inicial de plântulas de arroz. Encicl. Biosf. 8(15), 2337-2345.

Santos, P.C., M.S.M. Freitas, S.J. Freitas, M.P.S. Silva, and S.S. Berilli. 2011. Fungos micorrízicos no crescimento e nutrição de rebentos oriundos de coroa de abacaxi. Rev. Bras. Frutic. 33(Num. Spe. 1), 658-665. Doi: 10.1590/S0100-29452011000500092

Schlindwein, G., L.K. Vargas, B.B. Lisboa, A.C. Azambuja, C.E. Granada, N.C. Gabiatti, F. Prates, and R. Stumpf. 2008. Influência da inoculação de rizóbios sobre a germinação e o vigor de plântulas de alface. Ciênc. Rural 38(3), 658-664. Doi: 10.1590/ S0103-84782008000300010

Silva, A.A., A.J.C. Carvalho, F.P. Freitas, P.G.O. Pessanha, P.C. Santos, M.P.S. Silva, T.S. Vasconcelos, and F.L. Olivares. 2016. Diazotrophic bacteria and nitrogen fertilization on the growth of micropropagated pineapple plantlets during acclimatization. Ciênc. Rural 46(11), 1952-1958. Doi: 10.1590/0103-8478cr20141338

Souza, F.V.D., A.S. Souza, J.A. Santos-Serejo, E.H. Souza, T.G. Junghans, and M.J. Silva. 2009. Micropropagação do abacaxizeiro e outras bromeliáceas. pp. 177-205. In: 
Junghans, T.G. and A.S. Souza (eds.). Aspectos práticos da micropropagação de plantas. Embrapa Mandioca e Fruticultura Tropical. Cruz das Almas, Brazil.

Spaepen, S., J. Vanderleyden, and R. Remans. 2007. Indole-3-acetic acid in microbial and microorganism-plant signaling. FEMS Microbiol. Rev. 31(4), 425-448. Doi: 10.1111/j.1574-6976.2007.00072.x

Szilagyi-Zecchin, V.J., A.F. Mógor, L. Ruaro, and C. Röder. 2015. Crescimento de mudas de tomateiro (Solanum lycopersicum) estimulado pela bactéria Bacillus amyloliquefaciens subsp. plantarum FZB42 em cultura orgânica. Rev. Ciênc. Agr. 38(1), 26-33.

Taiz, L., E. Zeiger, I.M. Møller, and A. Murphy. 2017. Fisiologia e desenvolvimento vegetal. 6 th ed. Artmed, Porto Alegre, Brazil.

Terra, A.B.C., F.R.C. Souza, J.R. Mantovani, A.V. Rezende, and L.A. Florentino. 2019. Physiological characterization of diazotrophic bacteria isolated from Brachiaria brizantha rhizosphere. Rev. Caatinga 32(3), 658-666. Doi: 10.1590/1983-21252019v32n310rc 